THI Agriculture
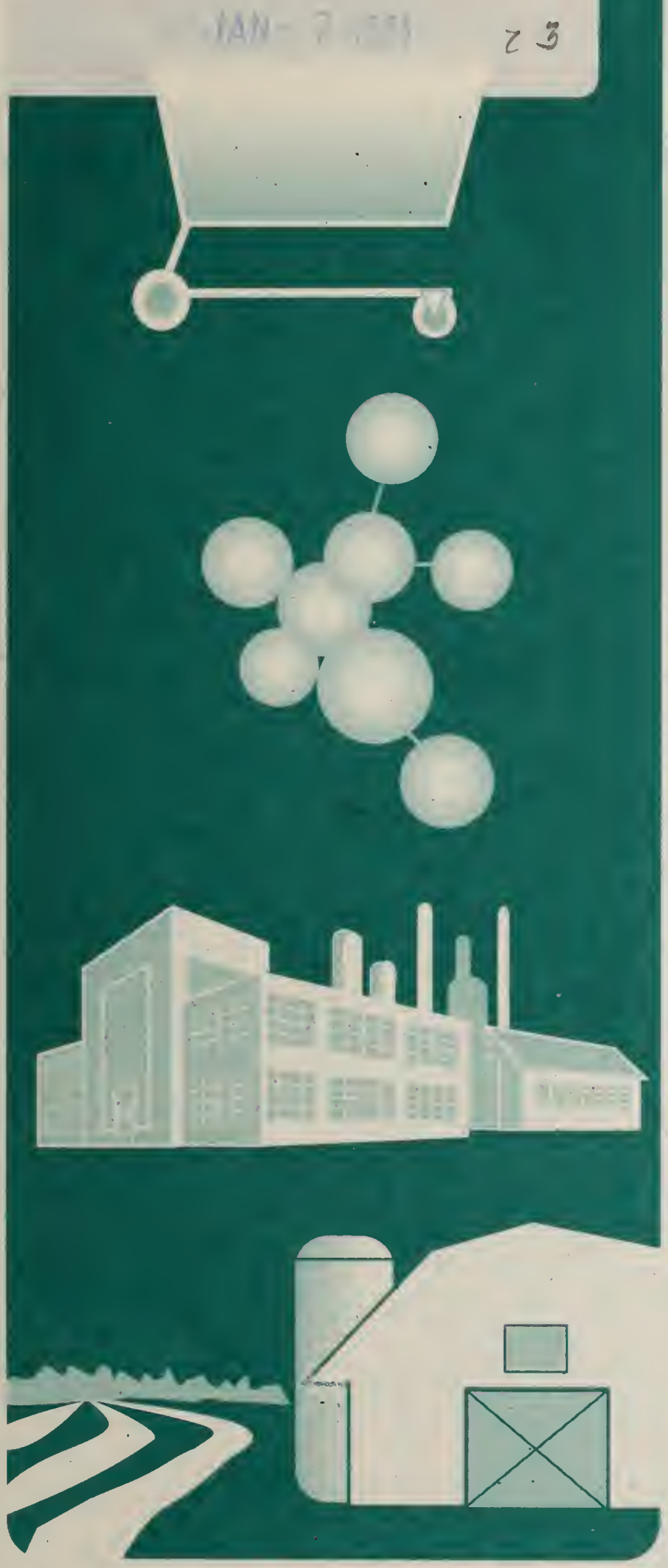

Research Branch Technical Bulletin 1993-7E Wheat transformation technologies

$27 \%$ 


\section{Cover illustration}

The images represent the Research Branch's objective:

to improve the long-term competitiveness of the Canadian agri-food sector through the development and transfer of new technologies.

Designed by Research Program Service.

\section{Illustration de la couverture}

Les dẹssins illustrent l'objectif de la Direction générale de la recherche : améliorer la compétitivité à long terme du secteur agro-alimentaire canadien grâce à la mise au point et au transfert de nouvelles technologies.

Conception par le Service amx programmes de recherches. 


\section{Wheat transformation technologies}

JOHN SIMMONDS and DAINA SIMMONDS

Plant Research Centre Agriculture Canada

Ottawa, Ontario K1A 0C6

Technical Bulletin 1993-7E

Research Branch

Agriculture Canada 
Copies of this publication are available from Director Plant Research Centre Research Branch, Agriculture Canada Central Experimental Farm

K.W. Neatby Building

Ottawa, Ont. K1A 0C6

Produced by Plant Research Centre

(C) Minister of Supply and Services Canada 1993

Cat. No. A54-8/1993-7E

ISBN 0-662-20931-1

Printed 1993 
CONTENTS

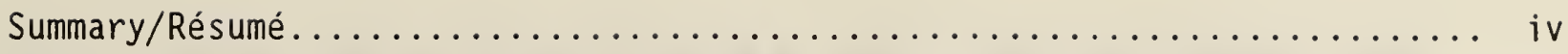

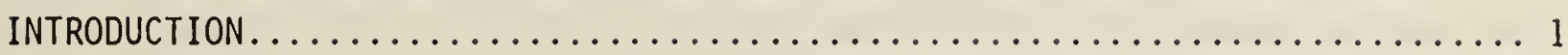

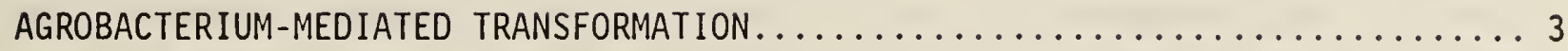

DIRECT DNA TRANSFER AND PROTOPLASTS $\ldots \ldots \ldots \ldots \ldots \ldots \ldots \ldots \ldots \ldots \ldots \ldots \ldots \ldots \ldots \ldots \ldots \ldots \ldots$

IMBIBITION OF DNA ACROSS THE CELL WALL $\ldots \ldots \ldots \ldots \ldots \ldots \ldots \ldots \ldots \ldots \ldots \ldots \ldots \ldots \ldots \ldots \ldots$

DIRECT DNA TRANSFER INTO CELLS THROUGH

RUPTURED CELL WALLS............................ 8

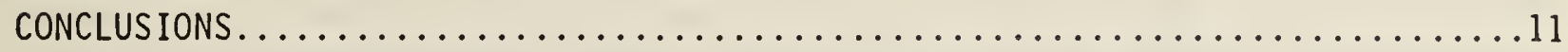

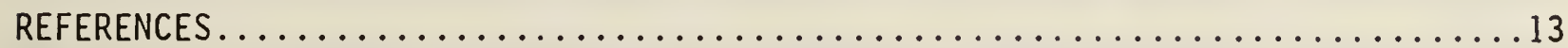


Rapidly developing technologies in plant molecular biology and cell biology have created the possibility of introducing novel genes into crop plants in order to affect specific agronomic traits. Wheat is one of the most important food crops in the world and it can be anticipated that genetic engineering to affect quality, productivity or sustainability will have a significant impact on agricultural economies. The development of transformation systems for the graminaceous cereals has been particularly difficult because Agrobacteriummediated gene transfer is not applicable. This review described progress with methods of direct DNA delivery to cereals; evaluates the evidence for claims of integration of foreign genes into the plant genome and discusses the potential of developing tissue culture independent transformation systems to eliminate somaclonal damage and to provide genotype independent technology applicable directly to elite cultivars.

\section{RÉSUMÉ}

La progression rapide des techniques de biologie moléculaire et cellulaire végétale ouvre la voie à l'introduction, chez des productions végétales, de gènes nouveaux qui modifient des caratères agronomiques particuliers. Le blé est l'une des cultures vivrières les plus importantes au monde. On prévoit que les manipulations de génie génétique, qui modifient la qualité, la productivité et la durabilité, auront un impact considérable sur les économies agricoles. La mise au point de systèmes de transformation chez les céréales de la famille des graminées a été particulièrement difficile, parce que, dans ce cas particulier, Agrobacterium ne peut servir à transférer des gènes. Le présent document décrit les progrès réalisés dans les méthodes d'introduction direct d'ADN dans des céréales, évalue les données étayant les allégations d'intégration de gènes étrangers au génome végétal et examine les possibilités de mettre au point des systèmes de transformation $n^{\prime}$ ayant pas recours aux cultures de tissus, afin d'éliminer les dommages somaclonaux et d'utiliser une technique sans lien avec le génotype, applicable directement aux cultivars élites. 
INTRODUCTION

Wheat with an annual world production on 226 million hectares of about 550 billion tonnes valued at nearly $\$ 80$ billion, is clearly one of the most important food crops in the world. Furthermore improvement in quality, productivity, or sustainability of such a major source of nutrition can be expected to have a significant impact on agriculture.

During the past few decades, advances in plant cell culture and recombinant DNA technology have created the potential to transfer genes from any organism into plant cells. In principle, a gene influencing a single trait can be isolated and transferred to a superior cultivar without concomitant transfer of undesirable traits, which normally occurs using classical breeding methods. As such, this technology would complement and enhance the efficiency of wheat breeding.

The most successful procedures for gene transfer into plants have been based on Agrobacterium-mediated gene delivery. Agrobacterium tumefaciens and $A$. rhizogenes are pathogenic bacteria that have evolved the capacity of delivering DNA from their Ti or Ri plasmids, respectively, into cells of a wide variety of dicotyledonous and some monocotyledonous plants. Incorporation of the transferred DNA (T-DNA) into the nuclear genome of the $\mathrm{plant}$ cell and its resultant expression causes a pathogenic response that includes tumor formation. To take advantage of nature's way of putting foreign genes into plant cells, molecular biologists have disarmed the $\mathrm{Ti}$ plasmid by removing the genes responsible for the tumorigenic response. It was then possible to incorporate 
any desirable gene into the T-DNA, which could then be transferred to plant cells and integrated into the host genome. Provided that these transformed cells can be induced to regenerate into plants, novel transgenic plants can be produced. While the Ti-based system is currently the method of choice for deivering DNA into many plants, the limited host range of Agrobacterium infection precludes its use in a large number of species, in particular the graminaceous cereals.

To overcome this host range limitation, numerous procedures have been developed for delivering DNA directly into plant cells, i.e., without a biological vector. These procedures include,

- imbibing cells or tissues in DNA solutions,

- transferring DNA into protoplasts by destabilizing the plasmamembrane either with polyethylene glycol (Armstrong et al. 1990) or by electroporation (Fromm et a1. 1986),

- rupturing the cell wall with laser beams, microprojectile bombardment, or by microinjection to overcome the cell wall barrier.

To date, the most promising transformation systems for wheat are by bombardment of DNA-coated microprojectiles into embryogenic callus cultures (Vasil et al. 1992) or by microinjection of DNA into apical meristem cells, which subsequently develop into pollen or ovules (Simmonds et al. 1992).

The development of transformation systems for the graminaceous cereals remains fraught with problems (Potrykus 1989). Numerous transformation systems have been attempted with wheat and some have yielded potentially encouraging results. However, in many studies claims of transformation are ambiguous because strict criteria for proof of integration of the foreign gene were not applied 
(Potrykus 1991). Proof of integration must include the following criteria:

- controls for treatment and analysis

- good correlation between physical (e.g., Southern blot) and phenotypic (e.g., enzyme assay) data

- complete Southern analysis containing

(a) the predicted signals in high molecular weight DNA

(b) hybrid fragments containing host DNA and the foreign gene

(c) the complete gene

(d) controls showing evidence of the absence of contaminating DNA fragments

- molecular and genetic analysis of the offspring populations.

In this review the various approaches to transforming wheat are examined and evaluated with respect to these criteria.

\section{AGROBACTERIUM-MEDIATED TRANSFORMATION}

Although the graminaceous cereals show limited susceptibility to Agrobacterium encouraging progress with this method has been made by the demonstration of agroinfection of maize with cloned DNA of maize streak gemini virus (Grimsley et al. 1987) and wheat with wheat dwarf gemini virus DNA (Hayes et al. 1988). Agroinfection is defined as the introduction of plant infectious agents via Agrobacterium and is limited to those cases involving molecules that can replicate independently of the plant chromosomal DNA. Agroinfection of cereals is an important discovery as it provides evidence that Agrobacterium can 
delivered DNA can be integrated into the plant genome of cereals. Mature rice embryos, inoculated with a supervirulent strain of Agrobacterium, formed tumorigenic callus tissue. A disarmed strain carrying genes for B-glucoronidase (GUS) activity and kanamycin resistance produced kanamycin resistant callus showing GUS activity. Molecular evidence indicated that T-DNA had been integrated into the rice genome (Raineri et al. 1990). Similarly, molecular analyses of wheat plants produced from florets inoculated with Agrobacterium just prior to anthesis suggested that T-DNA had been incorporated into the plant genome (Hess et al. 1990). However, without any evidence from progeny analyses indicating that the transgenes are heritable, such claims should be treated with caution. A critical assessment of Agrobacterium-mediated transformation of wheat (Langridge et al. 1992) provided only superficial evidence of DNA transfer from the bacterium to the plant. Embryos derived from florets inoculated with Agrobacterium carrying an antibiotic resistant gene showed elevated resistance to the antibiotic. Southern hybridization analysis of resistant plants showed positive signals. However, identical banding patterns were seen for every putative transformant. The generation of only one pattern of DNA fragments implies that the foreign DNA had inserted at the identical site in each transformation, a most improbable event. Furthermore, the progeny of these putative transformants were negative in Southern analysis. In conclusion, Agrobacterium-mediated transformation has not been successful in wheat. Nevertheless, DNA has been transferred to the plant and has persisted for one generation. A possible explanation is that T-DNA was transferred to an endophytic bacterium present at the time of inoculation. 


\section{DIRECT DNA TRANSFER AND PROTOPLASTS}

The cell wall, a physical and chemical barrier, can be removed by enzymatic digestion to produce viable protoplasts (Kao et al. 1971). Membranes can then be permiabilized with polyethylene glycol (Armstrong et al. 1990) or by electroporation (Fromm et al. 1986) to allow DNA uptake by protoplasts. These procedures have been used initially with Triticum monococcum protoplasts (Lorz et a1. 1985) and subsequently with $T$. aestivum (0ard et al. 1989) to identify constructs most suitable for wheat transformation studies. Transient expression assays using chloramphenicol acetyl transferase (CAT) and neomycin phosphotransferase II (NPT II) in $T$. monococcum protoplasts showed that the kinetics of delivery of DNA were similar to those for dicot protoplasts but the expression was generally 10-100 times lower in monocots (Hauptmann et al. 1988). It was also demonstrated that the CaMV $35 \mathrm{~s}$ promoter gave higher levels of expression that nopaline synthase promoter. Subsequently, 35s-NPT II fusions were used to generate stable transformants of $T$. monococcum nonregenerable calli (Hauptmann et al. 1988). An important advance was made with the demonstration that the inclusion of an $A D H ~ l$ intron in gene fusions significantly increased gene expression in maize (Callis et al. 1987). Inclusion of an intron near the $5^{\prime}$ end of the mRNA increased the expression of CAT, NPT II, and firefly luciferase coding regions by $200-$ fold. The importance of including introns in gene constructs for wheat transformation was established by the demonstration that the inclusion of a maize intron in a $35 \mathrm{~s}$-CAT construct gave a 185-fold increase in activity in $T$. aestivum protoplasts (0ard et a1. 1989). Similarly, $T$. monococcum and $T$. aestivum protoplasts were used to show that the maize ADH 1 promoter gave higher expression than the CaMV 35 s promoter. Inclusion of the 
$A D H 1$ intron and various enhancer elements with the $A D H$ promoter ( $p E m u$ ) consistently produced 40 -fold more GUS activity in wheat cells than did a similar 35s fusion construct (Last et a1. 1991).

The generation of transgenic wheat from protoplasts remains elusive because of the difficulty of obtaining regenerable cultures. Harris et al. (1988) regenerated plants from protoplasts of an anther-derived cell suspension, but they did not survive to maturity. Plants have been regenerated from protoplasts isolated from suspension cultures of immature embryo callus (Vasil et al. 1990, Wang and Nguyen 1990, Chang et a1. 1991). These plants showed a considerable degree of somaclonal variation resulting in arrested development and both male and female sterility. Nevertheless, nonregenerable cultures can be exploited for gene expression studies and for developing selection protocols (Simmonds and Grainger 1993). In view of major cytological problems associated with wheat protoplast cultures (Karp et al. 1987), a plethora of alternative methods to deliver DNA into cells or tissues were explored.

IMBIBITION OF DNA ACROSS THE CELL WALL

Pollen-mediated transformation resulting from the incubation of mature pollen or of germinating pollen in DNA solutions prior to pollination has been investigated in a number of laboratories. Genomic DNA (Ohta 1986) or constructs with reporter genes have been used with maize pollen (Booy et al. 1989) and with wheat pollen (Picard et al. 1988), but despite claims of integrative transformation (De Wet et a1. 1985), definitive proof has not been established. 
It would be expected that nuclease activity associated with germinating pollen would be a major problem with this approach. Complete degradation of large amounts of plasmid DNA by nucleases released from germinating maize pollen could be demonstrated within minutes of mixing the DNA and pollen (Booy et al. 1989).

The transfer of DNA into the zygote through pollen tubes in cut pollinated pistils was claimed to be an effective transformation system for rice (Luo and Wu 1988) and wheat (Picard et al. 1988) but the molecular evidence for transformation was ambiguous. Although this approach appears to be very simple and direct, it has not been reproducible in other laboratories. The presence of callose plugs and nuclease activity in the pollen tube are some problems associated with this technique.

A simple procedure of soaking isolated dry embryos of wheat, barley, rye, triticale, oat, and maize in DNA solutions resulted in the transient expression of reporter genes (Topfer et a1. 1989), but there was no molecular evidence of stable integration into the plant genome. A modification of this approach, in which an attempt was made to electrophoretically transfer DNA into germinating barley seeds al so failed to demonstrate integrative transformation (Ahokas 1989).

Electroporation of DNA into leaf-base segments of rice, maize, barley, and wheat was used to obtain transient gene expression (Dekeyser et al. 1990). Electroporation of immature zygotic embryos and embryogenic callus cultures of maize produced transgenic plants. Integration of the foreign DNA into the maize genome was clearly demonstrated and the gene was transmitted to the progeny of the transformants in a Mendelian fashion. The transgenic maize were not 
chimeric, which suggested that regeneration had occurred from single transformed cells. The application of this procedure to wheat requires a regeneration system from single cells of the superficial cell layer. To date, no such system is available. Macroinjection, a process that involves the injection of DNA through large needles to deliver DNA into extracelluar spaces, has been proposed as a transformation procedure. DNA would then have to move across the cell wall into intact cells. Attempts to macroinject ovules and embryos have failed, but success was reported with a floral meristem system. A reporter gene, when injected into the stem below the developing spike of rye, 14 days prior to meiosis, was subsequently expressed in selected offspring (De la Pena et a1. 1987). Unfortunately, numerous large-scale experiments using this technique with barley, maize, rice, rye, and wheat have failed to produce transgenic plants.

Transformation procedures that require DNA solutions to pass through the cell wall are limited because DNA will bind readily to cell walls and because of the presence DNA degrading enzymes. The plasmamembrane will also remain a very effective barrier unless disrupted chemically or electrically.

\section{DIRECT DNA TRANSFER INTO CELLS THROUGH RUPTURED CELL WALLS}

Laser beams can be focused to dimensions of less than $1 \mu \mathrm{m}$ and used to cut holes in plant cell walls and membranes. DNA uptake through the micropuncture can be facilitated along an osmotic gradient by placing the recipient cells in hypertonic buffer. Transient expression of reporter genes has been demonstrated (Weber et a1. 1990). This technology is relatively new and its potential for 
producing transgenic cereals cannot be assessed at this time.

Silicon carbide fibers can facilitate the delivery of DNA into plant cells. Transient expression of reporter genes was obtained after vortexing maize suspension culture cells with DNA and silicon carbide fibers. Penetration of the cells by the fibers was observed by scanning electron microscopy and it seems likely that DNA adhering to the fibers could be carried into the cells. Subsequently, stable transformed herbicide-resistant maize cell lines were selected (Kaeppler et al. 1991). It appears that the application of this technique to embryogenic cultures could provide a relatively simple procedure for generating transgenic plants.

Another relatively new technology, using a biolistics process (Klein et al. 1987), has received considerable attention. This technique involves the acceleration of high-density micron-sized particles to velocities sufficient to penetrate through plant cell walls. DNA adhering to such microprojectiles is carried into the cell and it is either released directly into the nucleus or is transported there from the cytoplasm. In graminaceous cereals, transient expression of genes has been reported in maize (Klein et al. 1988), rice (Wang et al. 1988), barley (Kartha et al. 1989), and wheat (0ard et al. 1990). This procedure is limited by the low frequencies of transient $\left(10^{-3}\right)$ and integrative $10^{-6}$ ) events. Nevertheless, the high-velocity microprojectile process has been used to obtain stable transformed nonregenerable maize (Klein et al. 1989) and wheat cells (Vasil et al. 1991). More significantly, this procedure has yielded transformed embryogenic cultures of maize (Fromm et al. 1990) and wheat (Vasil et al. 1992); in maize numerous fertile transgenic plants have been established 
but in wheat only one male sterile plant was produced, which was rescued by outcrossing to establish a transgenic line. These examples offer the most encouraging approach to the transformation of cereals. However, it should be recognized that the process relies on efficient regenerable tissue culture systems; unfortunately tissue culture is genotype dependent: All the maize transgenics were obtained from cell lines derived from the B73 $\times$ Al88 hybrid genotype, which have exceptionally high embryogenic responses in culture. Similarly, the wheat line was selected for its high level of regeneration.

DNA can be delivered directly into plant cells by the process of microinjection. Glass microcapillaries are used to mechanically deliver DNA solutions into cells in such a way that the injected cell survives and proliferates. Stable transformation frequencies as high as $20 \%$ have been reported with tomato callus cells (Toyoda et a1. 1988). However, microinjection requires a high degree of technical skill and in comparison to particle bombardment only relatively few cells can be handled. The power of microinjection is in the ability to deliver DNA precisely into a cell of choice. This transformation method could be exceptionally effective if DNA could be targeted into gametes or their precursor cells so that transgenic plants could be produced by normal zygotic embryogenesis. This method would eliminate the need for genotype dependent regeneration and cell selection systems and would avoid problems of somaclonal variation. Transformation of sperm or egg cells and in vitro fertilization to generate transgenics by zygotic embryogenesis is appealing, but the micromanipulation techniques for this method are still preliminary (Kranz and Lorz 1990). Shoot apical meristems contain cell initials that generate the floral cell lineages; the transformation of such cells could 
result in the production of transformed gametes. Histological analysis of wheat apical meristems showed that the floral meristems are initiated from cells in the hypodermal (L2) layer (Sharmen 1983). When a cell in L2 divides, the orientation of the spindle is normally parallel to the outer surface of the apex, thus maintaining a single file of cells. This file of cells is generated by a few apical initial cells, possibly only three (Fig. 1). Transformation of an L2 apical cell in a vegetative apex would establish a transgenic sectorial chimera, which would contribute to the numerous floral meristems in the developing spike. Vegetative apical meristems of wheat, dissected for micromanipulation so that the LI and L2 layers can be viewed in bright-field microscopy (Fig. 2), will regenerate phenotypically normal fertile plants (Simmonds et al. 1992). Micropipettes could be inserted into cells of the L2 layer (Fig. 3) and fluorescein isothiocyanate labelled dextran (MW 1700) was used as a marker to develop microinjection technology for delivering DNA solutions into L2 cells (Fig. 4). The feasibility of this approach for transformation of wheat was demonstrated by the expression of reporter genes microinjected into apical cells (Figs. 5,6). The continued development of these microinjected cells into germline tissues offers the prospect of a tissue culture and genotype-independent transformation system that will have universal application.

\section{CONCLUSIONS}

The fundamental problem in the production of transgenic wheat lies not so much in the delivery or even in the integration or expression of the foreign DNA, but rather in the recognition of cells that can regenerate phenotypically normal 
fertile plants, and the ability to target DNA into these cells. Gametic tissues (pollen and ovules) are obvious targets and regenerable somatic tissues (embryogenic callus, Magnusson and Bornman 1985, or leaf-base tissue, Wernickle and Milkovits 1984) also have potential. Shoot apical meristems contain cells that generate the cell lineages of germ-like tissues and consequently these cells are also interesting targets for transformation studies.

Genetic transformation of wheat has been limited by the lack of an Agrobacterium-mediated gene transfer system. Evidence that Agrobacterium can transfer DNA into wheat cells is promising, especially if mechanisms controlling the integration of T-DNA are discovered. Recent improvements in the technology of delivering genes into cells by microprojectile bombardment and microinjection, and the availability of gene constructs optimized for expression in monocots, e.g., monocot promoters and introns, have resulted in significant progress in cereal transformation. Cell culture technology remains the major obstacle to routine transformation of cereals, but increased efforts to target DNA into germline cells will eliminate tissue culture alterations and provide a genotypeindependent means of transformation. 


\section{REFERENCES}

Ahokas, H. 1989. Transfection of germinating barley seed electrophoretically with exogenous DNA. TAG 77:469-472.

Armstrong, C.L.; Peterson, W.L.; Buchholz, W.G.; Bowen, B.A.; Sule, S.L. 1990. Factors affecting PEG-mediated stable transformation of maize protoplasts. Plant Cell Reports 9:335-339.

Booy,G.; Krens, F.A.; Huizing, H.J. 1989. Attempted pollen-mediated transformation of maize. J. Plant Physiol. 135:315-319.

Callis, J.; Fromm, M.; Walbot, V. 1987. Introns increase gene expression in cultured maize cells. Genes and Development 1:1183-1200.

Chang, Y.F.; Wang, W.C.; Warfield, C.Y.; Nguyen, H.T.; Wong, J.R. 1991. Plant regeneration from protoplasts isolated from long term cultures of wheat (Triticum aestivum L.). Plant Cel1 Reports 9:611-614.

Dekeyser, R.A.; Cleas, B.; De Rycke, R.M.U.; Van Montagu, M.C.; Caplan, A.B. 1990. Transient gene expression in intact and organized rice tissue. Plant Cel1 2:591-602.

De la Pena, A.; Lorz, H.; Sche11, J. 1987. Transgenic rye plants obtained by injecting DNA into young floral tillers. Nature 325:274-276. 
De Wet, J.M.J.; Bergquist, R.R.; Harlan, J.R.; Brink, D.E.; Cohen, C.E.; Newell, C.A.; De Wet, A.E. 1985. Exogenous gene transfer in maize (Zea mays) using DNA-treated pollen. Pages 197-209 in .... ed. Experimental manipulation of ovule tissues. Longman Inc., New York, N.Y.

Fromm, M., Taylor, L.P.; Walbot, V. 1986. Stable transformation of maize after gene transfer by electroporation. Nature 319:791-793.

Fromm, M.E.; Morrish, F.; Armstrong, C.; Williams, R.; Thomas, J.; Klein, T.M. 1990. Inheritance and expression of chimeric genes in the progeny of transgenic maize plants. Bio/Technology 8:833-839.

Grimsley, N.; Hohn, T., Davis, J.W.; Hohn, B. 1987. Agrobacterium-mediated delivery of infectious maize streak virus into maize plants. Nature $325: 177-179$.

Harris, R.; Wright, M., Bryne, M., Varnum, J.; Brightwe11, B., Schubert, K. 1988. Callus formation and plant regeneration from protoplasts derived from suspension cultures of wheat (Triticum aestivum L.). Plant Cell Reports 7:337-340.

Hauptmann, R.M.; Vasil, V.; Ozias-Akins, P.; Tabaeizadeh, Z.; Rogers, S.G.; Fraley, R.T.; Horsch, R.B.; Vasil, I.K. 1988. Evaluation of selectable markers for obtaining stable transformants in the Gramineae. Plant Physiol. 86:602-606. 
Hauptmann, R.M.; Vasil, V.; Ozias-Akins, P.; Tabaeizadeh, Z.; Rogers, S.G.; Fraley, R.T.; Horsch, R.B.; Vasil, I.K. 1988. Evaluation of selectable markers for obtaining stable transformants in the Gramineae. Plant Physiol. 86:602-606.

Hayes, R.J.; MacDonald, H.; Coutes, R.H.A.; Buck, K.W. 1988. Agroinfection of Triticum aestivum with cloned DNA of wheat dwarf virus. J. Gen. Virology $69: 891-896$.

Hess, D.; Dressler, K.; Nimmrichter, R. 1990. Transformation experiments by pipetting Agrobacterium into spikelets of wheat (Triticum aestivum L.). Plant Science 72:233-244.

Kaeppler, H.F.; Somers, D.A. 1991. Stable transformation of maize tissue cultures using silicon carbide fibres. Pages .... in .... (ed.) Proceedings 33rd annual maize genetics conference, Madison, Wisconsin.

Kao, K.N.; Gamborg, O.L.; Miller, R.A.; Keller, W.A. 1971. Cell divisions in cells regenerated from protoplasts of soybean and Haplopappus gracilis. Nature 232:124.

Karp, A.; Wu, Q.S.; Steele, S.H.; Jones, M.G.K. 1987. Chromosome variation in dividing protoplasts and cell suspensions of wheat. TAG 74:140-146.

Kartha, K.K.; Chibbar, R.N.; Georges, F.; Leung, N.; Caswell, K.; Kenda11, E.; Qureshi, J.A. 1989. Transient expression of chloramphenicol 
acetyltransferase (CAT) gene in barley cell cultures and immature embryos through microprojectile bombardment. Plant Cell Reports 8:429-432.

Klein, T.M.; Wolf, E.D.; Wu, R.; Sanford, J.C. 1987. High velocity microprojectiles for delivering nucleic acids into living cells. Nature $327: 70-73$.

Klein, T.M.; Fromm, M.; Wiessinger, A.; Tomes, D.; Schaaf, S.; Sletten, M.; Sanford, J.C. 1988. Transfer of foreign genes into intact maize cells with high-velocity microprojectiles. Proc. Natl. Acad. Sci. 85:4305-4309.

Klein, T.M.; Kornstein, L.; Sanford, J.C.; Fromm, M.E. 1989. Genetic transformation of maize cells by particle bombardment. Plant Physiology $91: 440-444$.

Kranz, E.; Lorz, H. 1990. Micromanipulation and in vitro fertilization with single pollen grains of maize. Sexual Plant Reprod. 3:160-169.

Langridge, P.; Brettschneider, R.; Lazzeri, P.; Lorz, h. 1992. Transformation of cereals via Agrobacterium and the pollen pathway: a critical assessment. The plant Journal 2:631-638.

Last, D.I.; Brettell, R.I.S.; Chamberlain, D.A.; Chaudhury, A.M.; Larkin, P.J.; Marsh, E.L.; Peacock, W.J.; Dennis, E.S. 1991. pEmu: an improved promoter for gene expression in cereal walls. TAG 81:581-588. 
Lorz, H.; Baker, B.; Schell, J. 1985. Gene transfer to cereal cells mediated by protoplast transformation. Mol. Gen. Genet. 199:178-192.

Luo, Z.X.; Wu, R. 1988. A simple method for the transformation of rice via the pollen tube pathway. Plant Molecular Biology Reporter 6:165-174.

Magnusson, I.; Bornman, C.H. 1985. Anatomical observations on somatic embryogenesis from scutellar tissues of immature zygotic embryos of Triticum aestivum. Physiologia P1antarum 63:137-145.

Oard, J.H.; Paige, D.F.; Dvorak, J. 1989. Chimeric gene expression using maize intron in cultured cells of breadwheat. Plant Cell Reports 8:156-160.

Oard, J.H.; Paige, D.F.; Simmonds, J.A.; Gradziel, T.M. 1990. Transient gene expression in maize, rice and wheat cells using an air gun apparatus. Plant Physiology 92:334-339.

Ohta, Y. 1986. High efficiency transformation of maize by a mixture of pollen and exogenous DNA. Proc. Nat'1. Acad. Sci. 83:715-719.

Picard, E.; Jacquemin, J.M.; Granier, F.; Bobin, M.; Forgeois, P. 1988. Genetic transformation of wheat (Triticum aestivum) by plasmid DNA uptake during pollen tube germination. Pages 779-787 in Proceedings in International wheat genetics symposium. Cambridge. Cambridge Univ. Press. Cambridge, England. 
Potrykus, I. 1989. Gene transfer to cereals: an assessment. Trends Biotech. 7: $269-273$.

Potrykus, I. 1991. Gene transfer to plants. Assessment of published approaches and results. Annu. Rev. Plant Physiol. Plant Mol. Biol. $42: 205-225$.

Raineri, D.M.; Bottino, P.; Gordon, M.P.; Nester, E.W. 1990. Agrobacteriummediated transformation of rice (Oryza sativa L.). Bio/Technology 8:3338.

Sharmen, B.C. 1983. Developmental anatomy of the inflorescence of bread wheat (Triticum aestivum L.) during normal initiation and when affected by 2,4D. Annals of Botany 52:621-639.

Simmonds, J.A.; Grainger, J.L. 1993. The toxicities of antibiotics to protoplast cultures of Triticum aestivum L. Plant Science 89: 209-214.

Simmonds, J.; Stewart, P.; Simmonds, D. 1992. Regeneration of Triticum aestivum apical explants after microinjection of germ line progenitor cells with DNA. Physiologia Plantarum 85:197-206.

Topfer, R.; Gronenborn, B.; Schell, J.; Steinbiss, H.H. 1989. Uptake and transient expression of chimeric genes in seed-derived embryos. Plant Cel1 1:133-134. 
Toyoda, H.; Matsuda, Y.; Utsumi, R.; Ouchi, S. 1988. Intranuclear microinjection for transformation of tomato callus cells. Plant Cell Reports 7:293-296.

Vasil, V.; Redway, F.; Vasil, I.K. 1990. Regeneration of plants from embryogenic suspension culture protoplasts of wheat (Triticum aestivum L.). Bio/Technology 8:429-434.

Vasil, V.; Brown, S.M.; Re, D.; Fromm, M.E.; Vasil, I.K. 1991. Stably transformed callus lines from microprojectile bombardment of cell suspension cultures of wheat. Bio/Technology 9:743-747.

Vasil, V.; Castillo, A.M.; Fromm, M.E.; Vasil, I.K. 1992. Herbicide resistant fertile transgenic wheat plants obtained by microprojectile bombardment of regenerable embryogenic callus. Bio/Technology 10:667-675.

Wang, W.C.; Nguyan, H.T. 1990. A novel approach for efficient plant regeneration from long term suspension culture of wheat. Plant Cell Reports 8:639-642.

Wang, Y.C.; Klein, T.M.; Fromm, M.; Cao, J.; Sanford, J.C.; and Wu, R. 1988. Transient expression of foreign genes in rice, wheat and soybean cells following particle bombardment. Plant Molecular Biology Reporter 11:433439.

Weber, G.; Monajembashi, S.; Wolfrum, J.; Greulich, K.-0. 1990. Genetic 
changes induced in higher plant cells by a laser microbeam. Physiol. Plantarum. 79:190-193.

Wernickle, W.; Milkovits, L. 1984. Developmental gradients in wheat leavesresponse of leaf segments in different genotypes cultured in vitro. J. of Plant Physiology 115:49-58. 

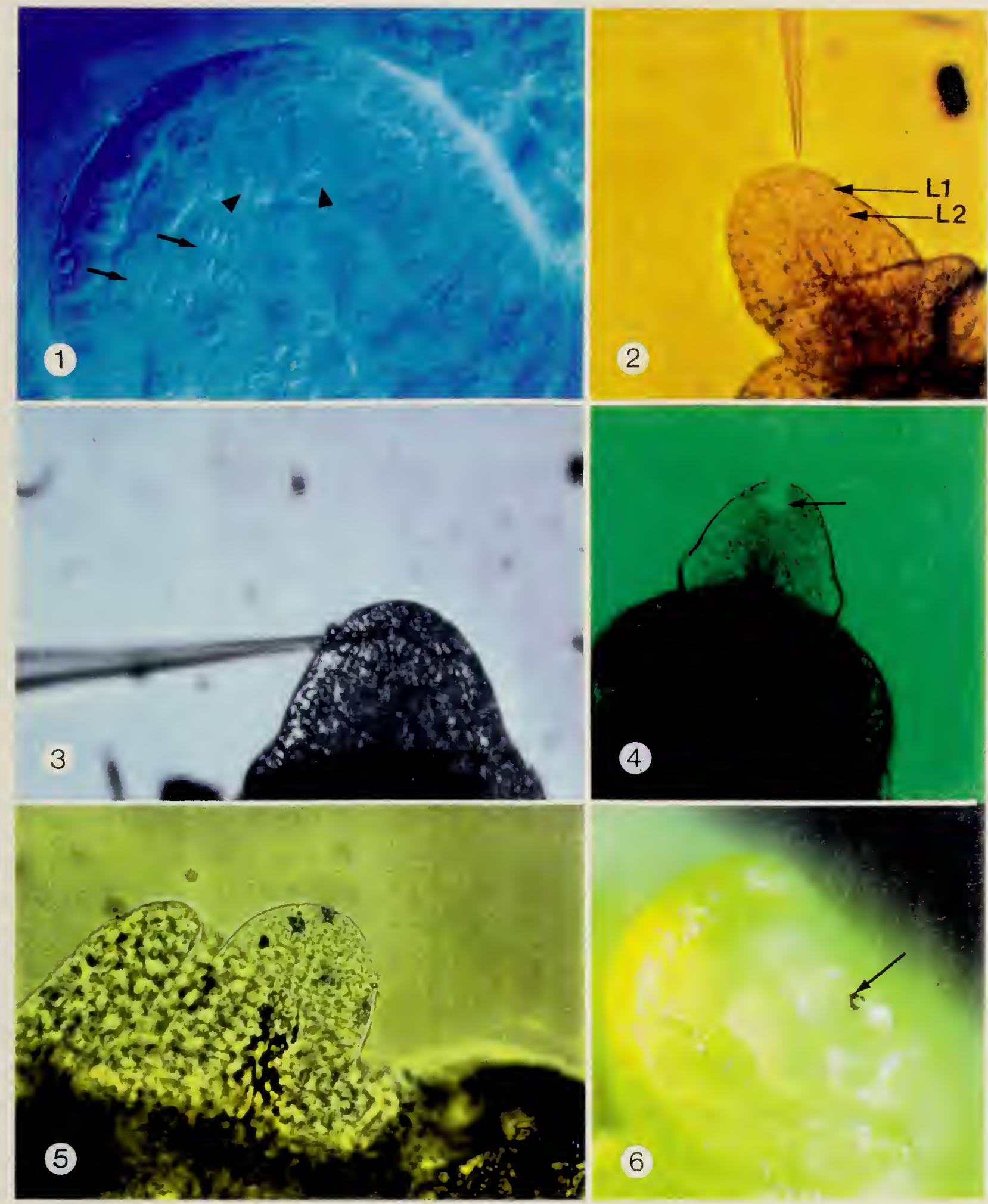

Figs. 1-6. Wheat apical meristem transformation system. (The mean diameter of apical domes is $100 \mu \mathrm{m}$.) 
Fig. 1. Optical sectionof a differential interference contrast micrograph shows the cell layers of the vegetative apex of wheat which are targets for DNA delivery. Apical initial cells (arrowheads) generate the L2 cell linkage from which floral meristems are derived. Note cell divisions in the L2 1ayer and central region of the apex (arrows).

Fig. 2. Bright-field micrograph of wheat apex with the micropipette positioned for injecting. Note that the LI and L2 cell layers can be distinguished.

Fig. 3. Micrograph shows the micropipette inserted into an apical initial of the L2 cell layer.

Fig. 4. A combination bright-field and fluorescence microscopy was used to show the successful delivery of a fluorescent dextran marker co-injected with DNA solution into both an LI and L2 (arrow) cells.

Fig. 5. Micrograph shows the wheat apex following the destructive histochemical assay for expression of B-glucuronidase (GUS) activity $48 \mathrm{~h}$ after injection with the GUS gene. The blue cells are evidence of foreign gene activity.

Fig. 6. Micrograph of a live wheat apical meristem showing red cells, a nondestructive assay for expression of anthocyanin. Corn genes, which regulate the biosynthesis of anthocyanin pigment, were injected into wheat apical meristem cells. Three days later these cells had produced the expected pigment (arrow). 


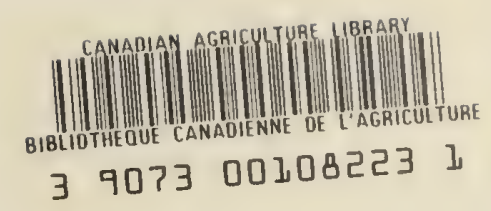


